Covered in: Web of Sciences (WOS); EBSCO; ERIH+; Google Scholar; Index Copernicus; Ideas RePeC; Econpapers; Socionet; CEEOL; Ulrich ProQuest; Cabell, Journalseek; Scipio; Philpapers; SHERPA/RoMEO repositories; KVK; WorldCat; CrossRef; CrossCheck

2019, Volume 11, Issue 2, pages: 256-269 | doi:10.18662/rrem/128

\section{Percept of Teachers Regarding Integration of Education for Environment and Sustainable Development in Primary Schools}

\author{
Gica PEHOIU ${ }^{1}$ \\ ${ }^{1}$ Associate Professor PhD, Valahia \\ University Targoviste, Romania, \\ gpehoiu@yahoo.com
}

\begin{abstract}
Environmental education studies emphasize the importance of this type of education since small ages as a basis for developing appropriate attitudes and behaviour towards the long-term environment, increasing accountability and motivation to take action to protect the environment. Geography has an essential role in environmental education, given the interdisciplinary character of this science, which aims at the interaction between man and environment, so that many studies are devoted to how this discipline contributes to forming of this type of education.

The present paper focuses on applying a questionnaire among teachers, they being discipline holders of some schools in Dâmbovița County (Romania), to highlight their perceptions, with the main reference to the concept of environmental education in primary school. Perceptual studies will therefore be useful in understanding the importance that respondents place on these issues, how the concepts of environmental education and sustainable development are focused to students, methods and techniques used predominantly in the undertaken activities.
\end{abstract}

Keywords: environmental education; sustainable development; geography; primary education; opinions; perceptions; attitudes.

How to cite: Pehoiu, G. (2019). Percept of Teachers Regarding Integration of Education for Environment and Sustainable Development in Primary Schools. Revista Romaneasca pentru Educatie Multidimensionala, 11(2), 256-269. doi:10.18662/rrem/128 



\section{Introduction}

Environmental education is a relatively new concept for global education, being dating back to the 1970s, and it was derived from the American school of this gender (Pehoiu, 2013; 2015). The emergence and development of the concept was brought by the United Nations Conference on the Human Dimension in Stockholm (1972) - Principle 19 of the 26 of the Stockholm Declaration, mentioning environmental education for both young people and adults (UNEP, 1972). Subsequently, two other international conferences have established environmental education worldwide (International Workshop on Environmental Education - Belgrade, Yugoslavia, October 1975, and the Intergovernmental Conference on Environmental Education Tbilisi, Georgia, 1977) - UNESCO, 1978.

The 80 's of the last century represented a period of development of environmental education globally, being introduced as a subject of study in the national programs of countries such as UK. UNESCO-UNEP, 1976 (United Nations Environment Program), established the International Environmental Education Program (1975-1990), which aimed at carrying out concrete actions on this type of education, promoting international cooperation and ideological exchange, coordination of research on environmental issues, development of new methods, curriculum, materials and programs, training courses (United Nations, 1987).

Since the '90s, environmental education has gained a new purpose, combining with education for sustainable development, thus defending a new concept, that of environmental education and sustainable development, which focuses on the current issues of human society (Pehoiu, 2013).

The most important international events that have defined the concept of sustainable development and, in particular, education for sustainable development, were:

- 1992 (Rio de Janeiro, Brazil): the United Nations Environment and Development Conference, where Agenda 21 was adopted, stating that education is the key element of sustainable development;

- Year 2000 - when the Millenium Development Goals are set, for which education has a decisive role;

- The 2005-2014 period - United Nations Yearbook on Education for Sustainable Development, the primary purpose of which was to give every citizen the opportunity "to benefit from education and to acquire values, behaviors and lifestyle necessary for a sustainable future and for a positive transformation of society" (UNESCO, 2009); 
- 2015 - The United Nations Summit on Sustainable Development, New York, adopting the Agenda for Sustainable Development 2030, with 17 Sustainable Development Goals (SDG), the development goal 4 referring to education, respectively Ensuring Quality Education for All and Promoting Lifelong Learning;

- 2016-2030 - The Global Action Program on Education for Sustainable Development, continuation of the Decade 2005-2014, aiming to achieve the sustainable development objectives until the year 2020.

The UNESCO coordinated program pursues two major objectives (https://en.unesco.org/gap), namely: reorienting education and learning so that all the population to have the opportunity to acquire knowledge, skills, values and attitudes by which they can contribute to a sustainable future; enhancing education and learning in all agendas, programs and activities that promote sustainable development. The same program has 5 priority action areas for integrating sustainable development education into national and international policies, transforming learning and the learning area (ecoschools or green campuses), developing teacher capacity, mobilizing young people and finding sustainable solutions at local level (UNESCO, 2017).

In this context, a unified definition of sustainable development education, respectively a learning process (or a didactic approach) based on the principles of sustainable development, involving all levels and types of education, has emerged. It refers to several types of learning to provide quality education and sustainable development of society: to learn to know, to learn to be, to learn to live together, to learn to self turn and also the society.

Therefore, the main issues that education for sustainable development at global level means are, among other things: poverty reduction, sustainable lifestyle, climate change, gender equality, etc.

The work is therefore based on international reference documents, marking the emergence and implementation of the concept of environmental education and, in particular, education for sustainable development. At the same time, the study also took into consideration the National Strategy for Sustainable Development of Romania - Horizons 2013-20202030, where special emphasis is placed on education, in order to achieve the objectives of sustainable development (National Strategy for Sustainable Development of Romania - Horizons 2013-2020-2030, 2008). 


\section{Learning objectives and specific competences of environmental education and sustainable development in primary education}

Education is particularly important in achieving sustainable development goals, and education for this issue involves building skills that help individual to reflect on own actions in terms of the current and future social, cultural, economic and environmental impacts (UNESCO, 2017).

Education for sustainable development requires the implementation of a new pupil-centered pedagogy, which should focus on interactive training, with emphasis on self-learning, participation and collaboration, problem solving, inter- and transdisciplinarity.

UNESCO (2017) mentions the following key competences that sustainable development education can develop:

- Systematic thinking - ability to recognize and understand relationships, to analyze complex systems;

- Anticipation - ability to understand and evaluate multiple likely future scenarios, probable or desirable, to create a perspective on prospects, assess the consequences of actions, address the risks and changes that may occur;

- Normative - ability to understand and reflect on the norms and values behind the actions; collectively;

- Strategic - ability to develop and implement innovative actions

- Collaboration - ability to learn from others, understand and respect the needs, perspectives and actions of others (empathy), to be sensitive to the needs of others, to solve potential conflicts;

- Critical thinking - ability to question the rules, practices and opinions, to reflect on their values, perceptions and actions, to take a stand against a given event;

- Self-awareness - ability to reflect on their own role in the local community and in the global society;

- Integrated problem solving - superior ability to apply various solutions to solve problems and complex problems related to sustainable environment, inclusive and equitable development that promotes this issue.

Among the learning objectives, those referring to cognitive (understanding and thinking), socio-emotional (collaboration, negotiation, communication, reflection, motivation), behavioral (action), etc. elements, are mentioned too (UNESCO, 2017).

Also, education for sustainable development is presented as a holistic concept that involves integrating this issue into teacher education and school 
curriculum within educational institutions (concept of school as a learning model and an appropriate learning environment - cross-country schools, green campuses), community and political and decision-making (Fig. 1).

Many studies have been developed detailing the competences of the teacher involved in environmental education and sustainable development, noting that the personality of the educator is very important in this respect, that it is important how the teacher transmits the knowledge to ensure a good understanding of the students and receptivity increased (Sencovici \& Pehoiu, 2017).

Understanding themes of sustainable development implies a specific pedagogical approach and more requirements (Bourn, Hunt, Blum, \& Lawson, 2016: 53), among which: the themes being associated with the transmission of basic values of society; promoting critical thinking and reflection; encouraging learner to make connections between his life and that of people from other parts of the world; providing opportunities for the students to have an active and positive engagement in the society, etc.

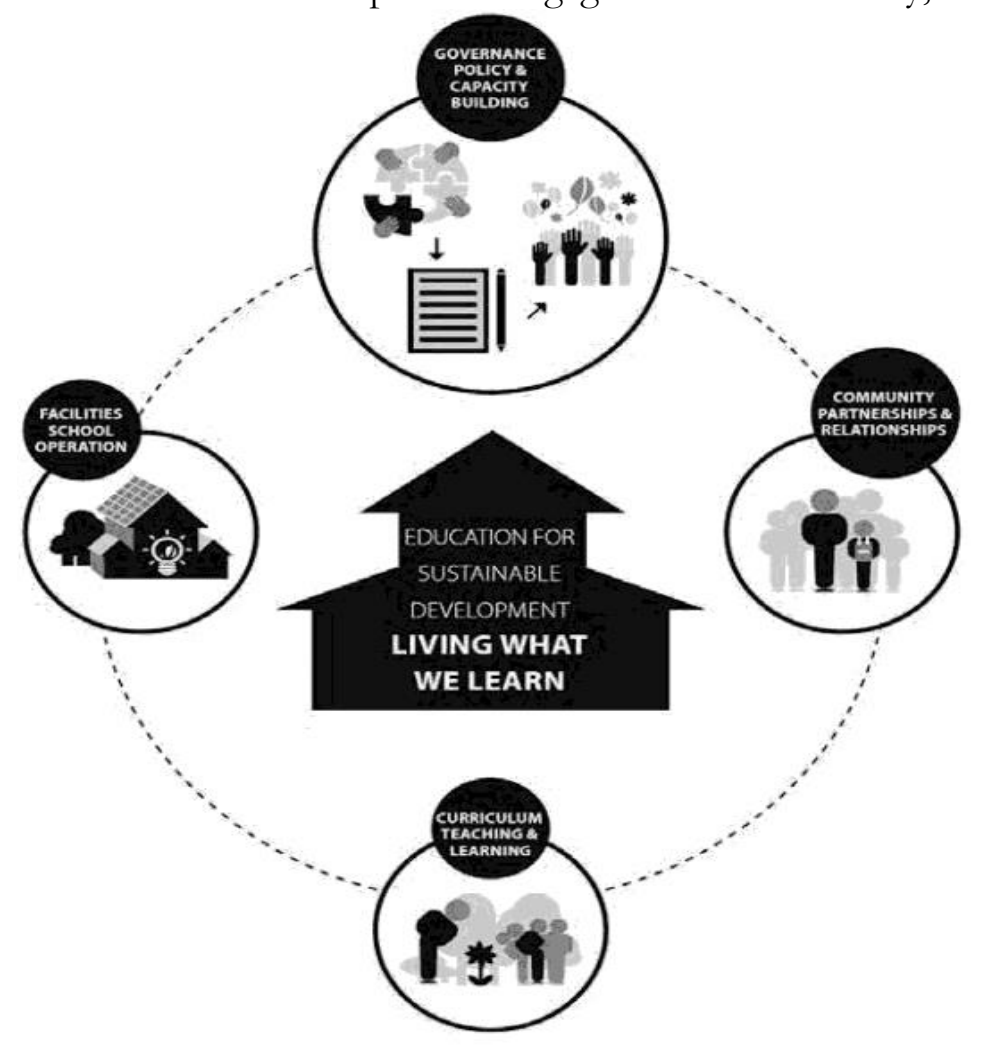

Fig. 1. An integrated approach to the concept of education for sustainable development (UNESCO, 2017) 


\section{Teachers' perception regarding integration of environmental education in primary school}

\subsection{Working methodology}

The working bypothesis of the present study is the involvement of the teaching staff in the process of teaching-learning of pupils in primary education, addressing issues of environmental education and sustainable development.

Purpose: The research aimed at diagnosing and enhancing the perception of teachers about the integration of environmental education and sustainable development into primary school.

General objectives:

- identifying how teachers perceive importance of environmental education;

- highlighting integration of environmental education in activities carried out with students in the classroom in primary education;

- understanding perception of finding best teaching and transcurricular methods of environmental education and sustainable development;

- motivate students to increase their interest and responsibility for environmental education.

Methods used: questionnaire survey, elaboration and application of the questionnaire, bibliographic study, analysis and adaptation of information from the literature, statistical processing of information, comparative analysis, graphic representations.

Sociological research. This study was based on a questionnaire survey, applied to a sample of 65 primary school teachers from schools from rural and urban areas of Dâmbovița county and being applied in February-March 2018.

The questionnaire contained 15 questions, of which 13 were variants and only two were open. The majority of the teachers who participated in the study are female (86\%), with a variable of education activity (3-45 years), and over $80 \%$ of them have higher education.

\subsection{Results and discussions}

The questionnaire contained a series of questions, including: "Do you know the most important terms defining environmental education?", "How could you define environmental education / sustainable development?", "What do you think are the primary education disciplines through 
which environmental activities can be done?", "From the list of global environmental issues that you consider the most important?", "Which of them do you think should be included in the curricula for study?", "Do you encounter problems in developing / teaching environment-specific activities and sustainable development?", "Where do you do such activities?", "What sources do you use?".

The analysis, processing and interpretation of the results of application of questionnaire highlights some aspects of the issue to which reference is made, among which:

- To the question What are the terms most often used in your work to define environmental education?, respondents have said they frequently use the term environmental education and education for environmental protection. In their responses, the phrase „education for environmental exploration” (7\%) was also mentioned as being derived most probably from the name of the mathematical curriculum area and the exploration of the environment (Fig. 2).

To the question Which of the aspects of environmental education do you put more emphasis on the class?, the four answer variants show that $57.5 \%$ of the respondents consider the motivation to take environmental actions and $47.3 \%$ the increase of the responsibility in making decisions (Fig. 3). Environmental awareness issues were selected by $18.9 \%$ of the respondents, while the cognitive part of environmental education, knowledge transfer was considered important by only $2.5 \%$ of them.

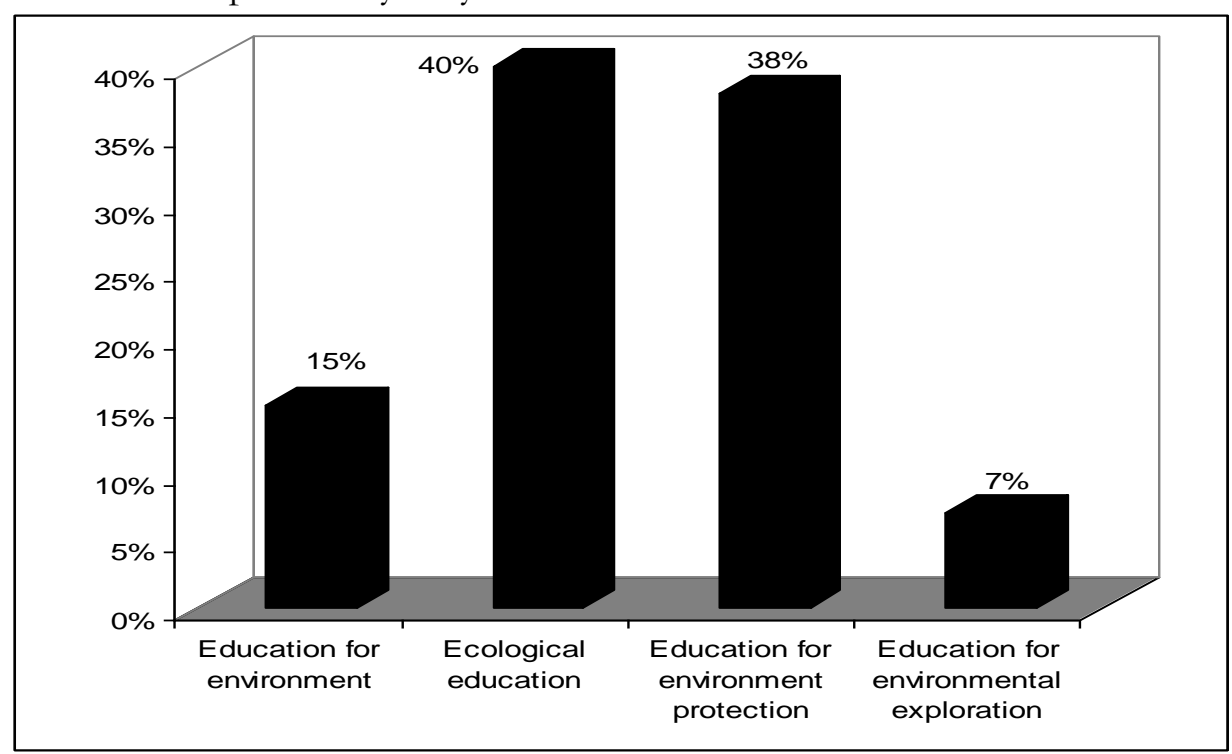

Fig. 2. Phrases used by teachers in defining environmental education 


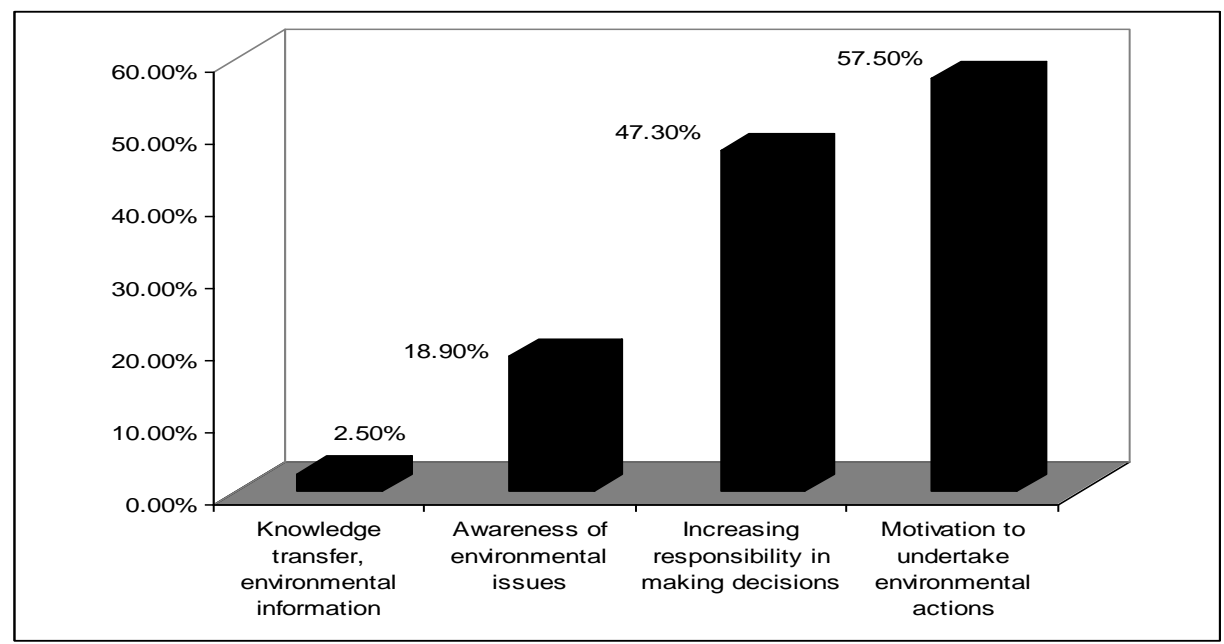

Fig. 3. Environmental education actions considered important by teachers

The primary education disciplines considered to have the greatest importance in environmental education among students are, in order of importance, designated: science, mathematics and environmental exploration, followed by communication in Romanian, geography, civic education and personal development, arts and practical skills. It is noticed that geography has not been designated by many teachers as having a particular importance, explicable also because the discipline is taught only in the fourth grade.

However, there is to be noted an increase in interdisciplinary at this level of education in terms of environmental education and sustainable development, meaning that respondents have also designated disciplines other than those devoted to the introduction of environmental notions such as personal development or arts and practical skills.

Another question of the questionnaire concerned Didactic knowledge of sustainable development, this concept having no special importance in the school curriculum for primary education, reflected also by the answers received: more than half of the respondents have only one idea general concept, while the rest know the concept well (Fig. 4). It is worth noting that all teachers know the concept, a relevant aspect for its integration into schools.

At the same time, teachers consider that this notion is very low represented in the curriculum of primary education (57\%), a rather large percentage even mentioning that it is not introduced at all $(23.5 \%)$, and only 
$19.5 \%$ considering that the notion is sufficiently integrated (School programs adopted, MEN, 2018).

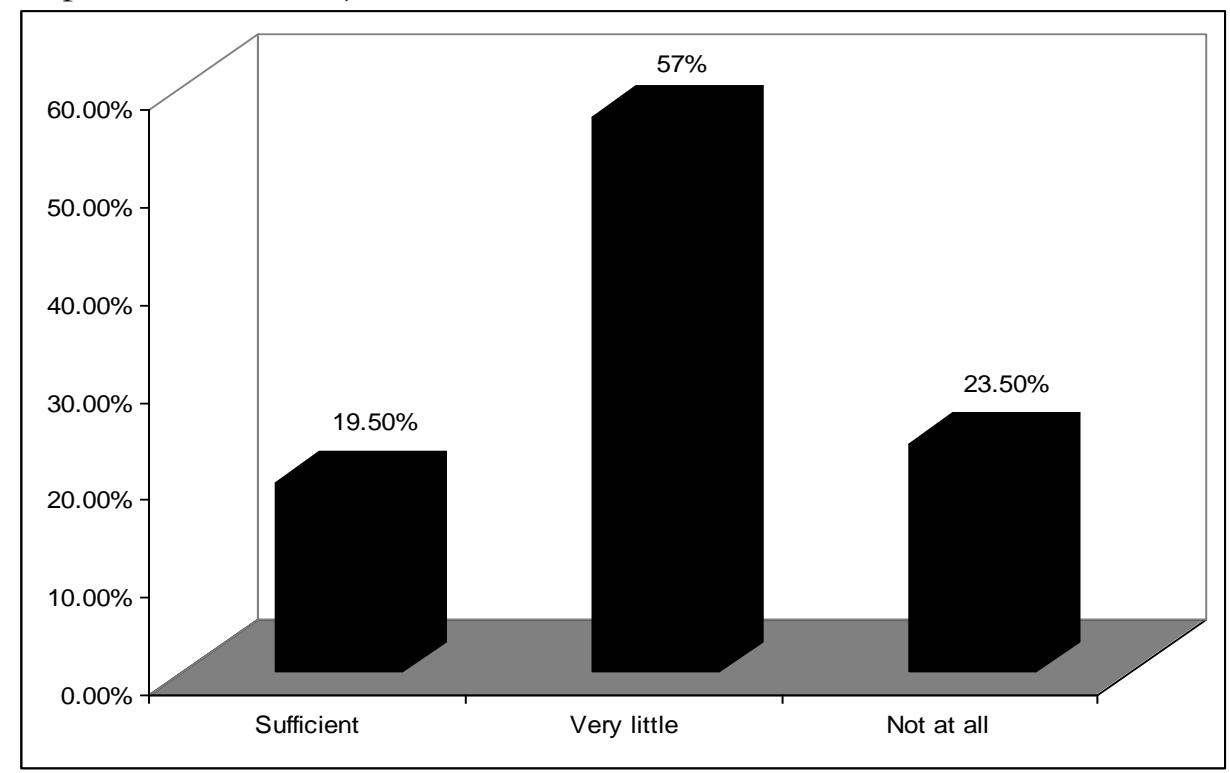

Fig. 4. Share of answers to the question: Is the notion of sustainable development part of the curriculum for primary education?

Another question emphasized the identification of the most important issues of the environment. In this respect, environmental pollution and environmental protection were among the main environmental issues under consideration (Fig. 5), most of which were followed by deforestation and waste issues problems. Climate change and exploitation of environmental resources have also been considered important by about half of those surveyed, followed by greenhouse effect and ozone depletion. The survey shows a much lower interest in the aspects of urbanization and risk phenomena, considered complex and probably more abstract notions for primary education. 


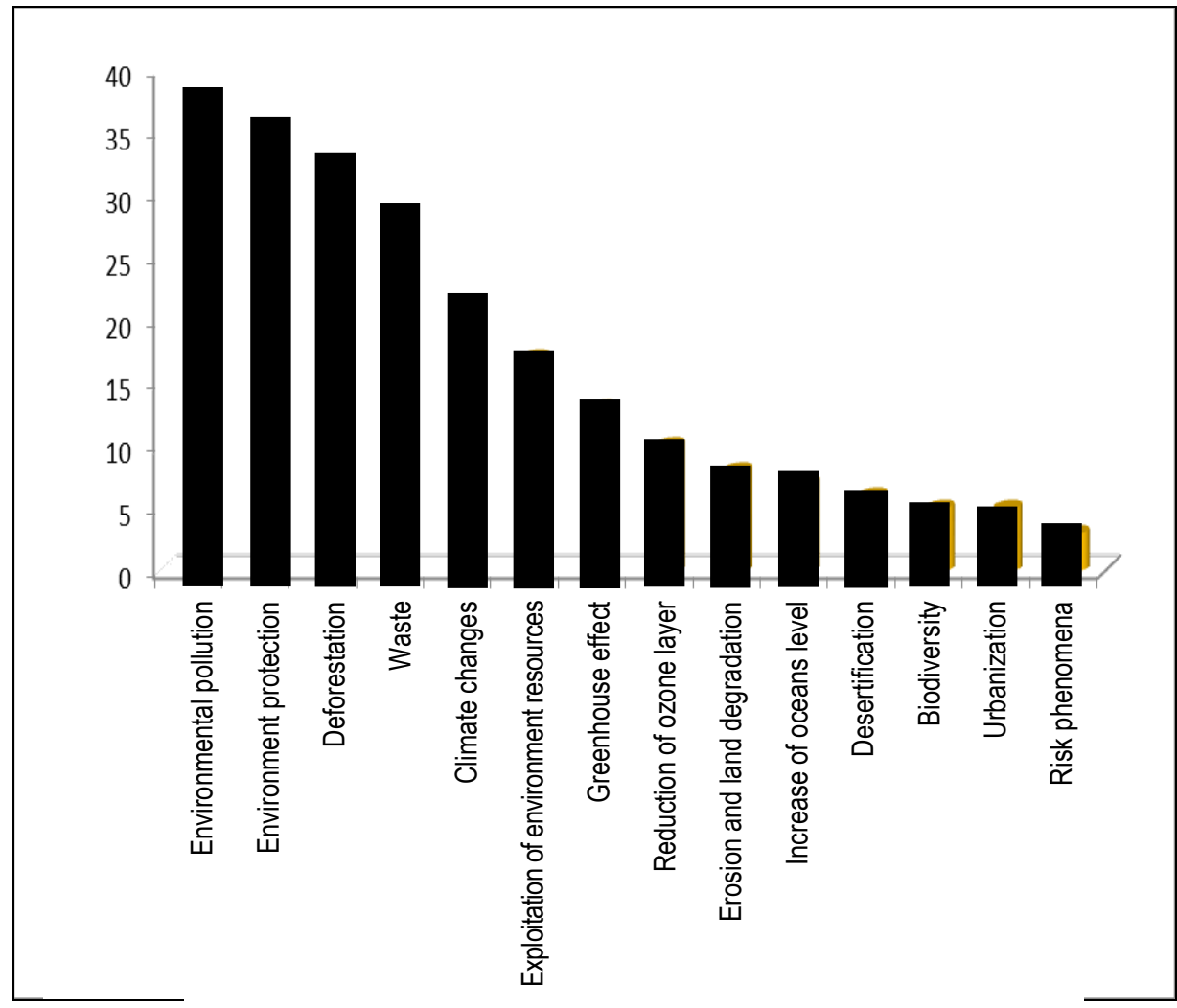

Fig. 5. Global environmental issues identified as important to be studied in primary education

There is some agreement between what teachers consider important and what is included in the school curriculum, since environmental issues, pollution and waste have all been mentioned as being included in primary education. However, there are no significant notions associated with global environmental issues identified as systematic, such as climate change, greenhouse effect, ozone depletion, increase of planetary ocean level, and so on.

To the question What problems do you encounter in teaching lessons with environmental notions and sustainable development in primary education?, most teachers mention as major difficulties the lack of appropriate teaching materials, inadequate allocation of time to teach these notions, but also the disinterest of students.

It is noted that the majority of teachers (almost $86 \%$ ) mention that they use the school auxiliaries (garden, school or certain laboratories) to 
teach environmental notions, which is appreciated in conveying long-lasting and concrete environmental notions through practical activities.

The main sources of information in the teaching of environmental notions are the Internet, specialized books and textbooks, followed by profile magazines and the media (Fig. 6). There have also been leaflets and brochures in the same sense. It also appears that the Internet is the most important source of information for teachers in this direction.

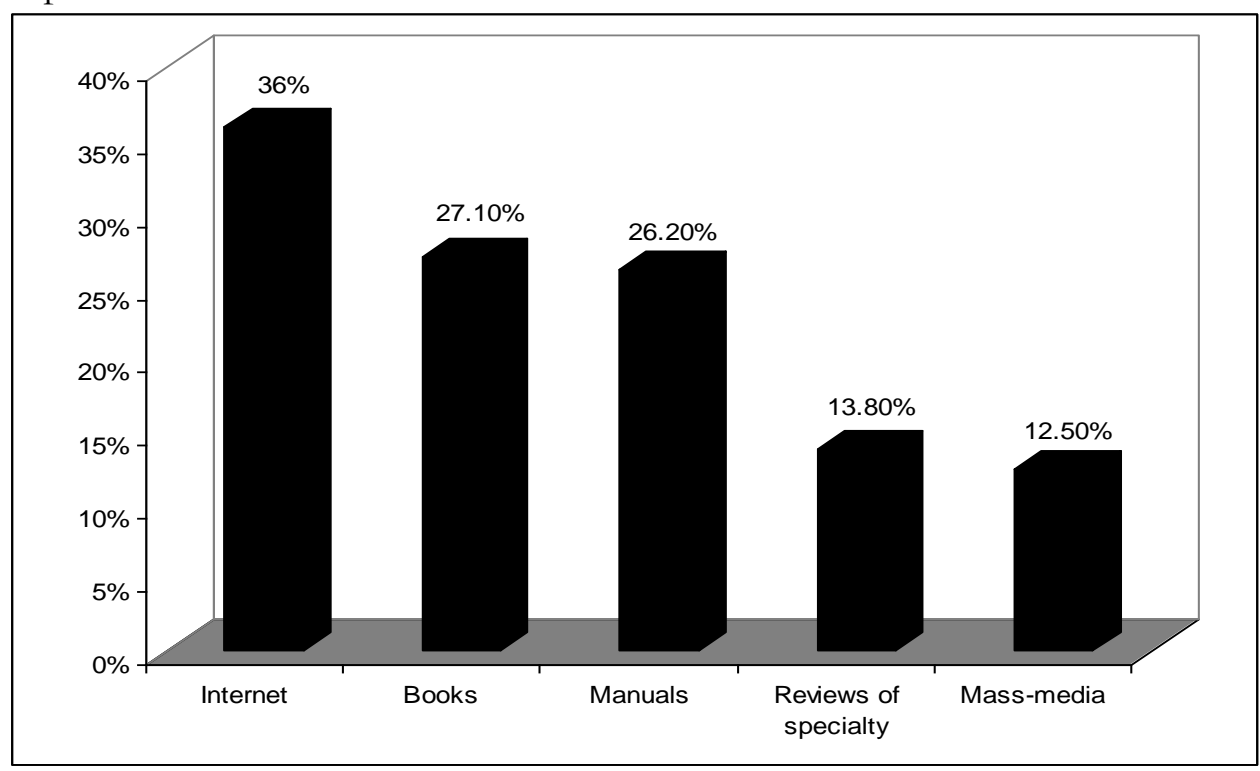

Fig. 6. The main sources of information used by teachers to teach environmental notions

Environmental education is an important aspect considered by teachers in primary education, approx. $67 \%$ of them mentioning it as an important element and being occasionally stressed, and the rest, while considering environmental education as a priority, state that they do not have enough opportunity to deal with these issues.

In this respect, there are remarkable in the didactic activity: waste collection, recycling, participation in exhibitions and thematic excursions, documentary films, environmental activities within the school otherwise, events on special ecological calendar days such as Earth or Forest Day, National Day of Cleanliness etc.; planting trees and flowers, making boxes for birds, participating in the Let's do it Romania! Program for waste collection and Let's get green! (a campaign to promote eco-education, the goal of which is to promote responsible behavior towards the environment in order to 
promote a green future); demonstrative lessons in projects such as SUSTAIN (a network of 11 institutions providing continuing professional development programs for teachers in 10 European countries, the mainstream education project for sustainable development) and PROFILES (a project promoting science education through scientific investigation); participation in various competitions on ecological issues, etc.

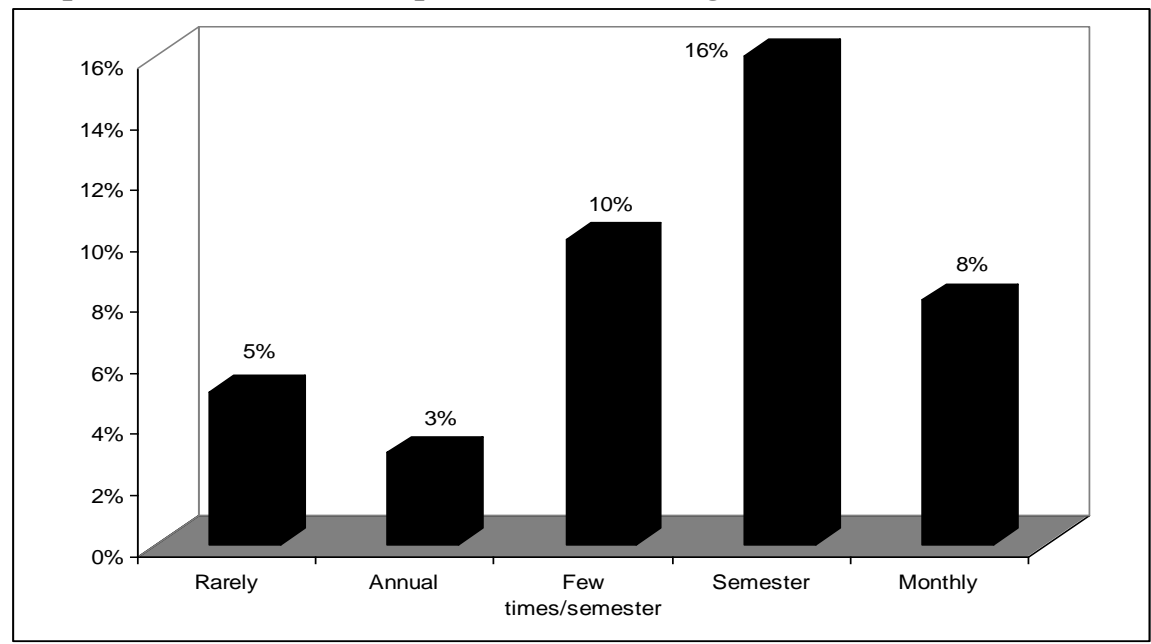

Fig. 7. Periodicity of the participation or organization of environmental actions in the schools participating in the study

It is noted that some activities dedicated to the environment are organized by the teachers at the level of pupils, but there are also schools that have participated in larger programs that included the school unit or local community.

From the responses received, such actions have a periodicity, especially half-yearly, or several times a semestrial and less monthly, but there are also teachers who participated / organized such activities only once a year or even less frequently (Fig. 7).

In organizing and conducting such activities, teachers require support from either authorities or parents, also from specialists or volunteers, as well as from NGOs.

\section{Conclusions}

Following application of the questionnaire to the teachers from the participating schools on perception of integration of environmental education and sustainable development in primary education, we can speak 
of optimistic perspectives in successful implementation of such activities in schools.

Therefore, as can be seen from the collection of the answers to applied questionnaire, teachers are interested in implementing new educational approaches focused on main ways of improving environmental education issues. This objective can be achieved through existing means and action-oriented actions at school and community level.

Teachers in the same sense also show an increased interest in diversifying concerns about environmental activities, aware of the positive impact they make on their own didactic training as well as on strengthening their relationships with students. In this respect, it is intended to increase their motivation and responsibility towards environmental care and to associate notions of as many disciplines as primary, and not only.

The issues most often debated by the teachers, according to the same results of the questionnaire, are mainly those related to pollution and environmental protection, waste management and deforestation. It is also noted that main difficulties encountered in addressing such issues are mainly related to the lack of appropriate teaching materials or the poor allocation of time spent on environmental issues in school curricula.

Also, as noted, it is also important to consider the teachers' interest in organizing and carrying out such activities on a regular basis, most of them being semestrial, but it is desirable to do more from this point of view. That is why it is necessary to involve specialized institutions and authorized persons in the development and implementation of such activities.

\section{Copyright}

This study represents totally the contribution of the main author and is not prepared using another sources, instead the bibliographical ones.

\section{References}

*** (2008). Strategia Națională pentru Dezvoltare Durabilă a României - Orizonturi 2013-2020-2030 (National Strategy for Sustainable Development of Romania - Horizons 2013-2020-2030), Bucureşti.

Bourn, D., Hunt, F., Blum, N., \& Lawson, H. (2016). Primary education for global learning and sustainability. York, UK: Cambridge Primary Review Trust.

Ministerul Educației Naționale (2018). Programele şcolare, în vigoare (https://edu.ro/).

Pehoiu, G. (2013). Ecological responsibility training in the present sustainable development context of the Romanian society, in the case of primary and 
secondary education. In The $5^{\text {th }}$ International Conference EDU-WORLD, Procedia - Social and Behavioral Sciences (pp. 637-642), Volume 76.

Pehoiu, G. (2015). Ecologic education and its reflection in the preuniversity educational system in Romania. In SGEM Conferences on Social Sciences and Arts, Book 1, Education and Educational Research (pp. 317-324), vol. II, 2015.

Sencovici, M., \& Pehoiu, G. (2017). Environmental education in school, family and community. In MEPDEV 2nd, 2016, Central \& Eastern European LUMEN International Conference - Multudimensional Education and Professional Development. Ethical Values (pp. 722-730).

UNEP (1972). Stockholm declaration on the human environment. United Nations Conference on the Human Environment, Stockholm, Sweden, New York United Nations Environment Programme.

UNESCO (1978). Intergovernmental Conference on Environmental Education, Tbilisi (USSSR), 14-26 October 1977, Final Report, UNESCO Paris (http://unesdoc.unesco.org/images/0003/000327/ 032763eo.pdf).

UNESCO (2009), Review of Contexts and Structures for Education for Sustainable Development Learning for a sustainable environment, $\mathrm{TH} / \mathrm{ESD} / 12$ / OS/009-E.

UNESCO (2017), Education for Sustainable Development Goals: Learning Objectives, (https://en.unesco.org/gap), ISBN 978-92-3-100209-0.

UNESCO-UNEP (1976). The Belgrade Charter. Connect: UNESCO/UNEP Environmental Education Newsletter, 1(1), 1-2.

United Nations (1987). Our Common Future Brundtland Report, World Commission on Environment and Sustainable Development. 